\title{
9. Decentralisation, local innovation and competition among cities
}

\section{David Dollar}

China's reform and opening (gaige kaifang) is best known for introducing elements of a market economy into what had previously been a rigidly planned system. Agricultural communes were broken up and farming returned to a family basis. Private foreign investment and trade were allowed—initially in a small number of special zones, but eventually throughout the whole country. A domestic private sector grew alongside the traditional state-owned enterprise sector. All of these were important and visible changes. But what is less well appreciated is that the reform also involved large-scale political decentralisation. Local governments were given much more autonomy than under the planned system. This produced two of the distinctive features of China's reform and development: first, it led to healthy competition among cities to create the best investment climates to attract, first, foreign investment and, then later, domestic investment; and second, it encouraged locales to seek innovative approaches to providing public goods. There are many examples of successful innovations in China being scaled up to benefit the whole country. Local innovation and competition were key factors in China's success.

\section{Decentralisation and reform}

Under the planned economy, China was largely cut off from global trade and investment. In the 1950s, it imported machinery and technology from the Soviet Union, but after the break between the two communist giants around 1960, China entered two decades of almost total isolation. The legacy of isolation and the Cultural Revolution was that China, at the end of the 1970s, was poorer by the standard official measures than sub-Saharan Africa, backwards technologically and in poor fiscal and financial condition.

After the death of Mao Zedong, a wide range of Communist Party officials, led by Deng Xiaoping, wanted to take the economy in a different direction. Deng believed that it was particularly important to open up the country to foreign ideas and technology. This notion was to a considerable extent still controversial, however, owing to the legacy of developed-country imperialism in China. Controversial new directions in Communist Party policy were often first tried on an experimental basis in a few locations, with good results then scaled up to the national level. In the case of opening up to foreign investment and trade, the party decided in 1979 to open 
four special economic zones that would be able to attract foreign investment and would have streamlined procedures for importing machinery and parts to be used in processing trade for export. Three of these zones were in cities in Guangdong and one in Fujian. Other cities quickly wanted to join the experiment. In 1984, another 14 cities were given the same opportunities as the special zones. In 1993, this was expanded to provincial capitals (more than 30) plus five inland cities along the Yangtze River and nine border cities (Eckaus 1997). Thus, within a relatively short time, dozens of Chinese cities had opened up to foreign trade and investment.

The implicit contract between the central government leaders and these local governments was clear: the government 'has no money. So we will give you a policy that allows you to charge ahead and cut through your own difficult road', Deng told party leaders at a policy meeting on the special zones in 1979 (Vogel 2011: 398). The central government did not have the resources to finance capital and technology imports, so local governments were encouraged to attract foreign investment. This policy set off intense competition among local governments to attract foreign investment. Foreign investors were interested in entering the Chinese market, and they had a large number of cities from which to choose. Investors were naturally attracted to cities that could streamline their local bureaucracy and centralise decision-making in a small number of government offices - the proverbial one-stop shop.

Deng's governing style encouraged this competition. According to Vogel (2011: 699700):

Deng pulled back on the governing structure that tried to penetrate everywhere. Instead of setting tight rules that local areas had to follow, he established a system in which governing teams, selected by the next higher level, were given considerable independence as long as they managed to bring rapid growth ... In Deng's era and in the decades after Deng, those judgments [on local government performance] were based overwhelmingly on how much the team contributed to China's overall economic growth.

Cities such as Shenzhen, Dongguan, Foshan and Xiamen developed reputations for being hospitable to foreign investors and for having local officials who could help investors cut through bureaucratic problems. These successes naturally spread to other cities since local officials everywhere knew that much of the prospect for career advancement would depend on investment and growth. In the early 2000s, the World Bank surveyed more than 10,000 firms in 120 Chinese cities and found considerable variation in local investment climates as measured, for example, by the amount of time spent dealing with red tape, customs clearance times or the reliability of critical infrastructure such as power supply (World Bank 2004). Cities with better investment climates perform better on a range of economic dimensions, including involvement in global value chains. 
Another key aspect of the local investment climate is infrastructure. China began its reform with very poor infrastructure and limited ability to address the gaps because of fiscal constraints. Some early policy decisions were key to resolving these bottlenecks. In the mid-1980s, the State Council allowed investments in the power sector to proceed on a cost-recovery basis. For a while, there was a dual pricing system in which 'old power' was very cheap, whereas 'new power' from recent investments was priced to cover the full cost of generation. New power spread quickly and eventually old power faded away, leaving China with a largely commercial power sector. The price of power has been higher in China than in many developing countries that subsidise it, but it is available and reliable. Similarly with roads: China has developed the largest system of toll roads in the world, with tolls that generally cover the cost of building and maintaining the network. This practical approach to infrastructure pricing enabled the key economic infrastructure-power, roads, seaports and airports - to expand quickly (Dollar 2008). Much of the financial responsibility for the infrastructure investment and management rests at the local level. Cities that could attract some initial foreign investment through better administration then had the capacity to finance investment in infrastructure, and the revenue stream from those investments spurred further expansion of the infrastructure network.

A final key issue in local industrial development was labour. Some of the locations that have risen to industrial prominence were little villages or towns with small populations at the beginning of the reform period. China began its reform with 80 per cent of its population in rural areas because the pre-reform system had maintained a rigorous household registration (bukou) system that prevented ruralurban migration. The hukou system continues to prevent permanent migration, but local officials found a way around this constraint through the use of migrant workers. Employers could recruit rural workers to come to work in factories, hotels and restaurants and construction activities. These migrants were typically young. They were not allowed to bring their families with them and they were not registered as urban residents, so they were not entitled to a full range of urban public services. This system was very supportive of rapid industrial development. Cities could attract workers, who lived in dormitories or on construction sites. There was no need for permanent housing, nor did the migrants make claims on the social services of the city government.

The number of migrant workers has risen from essentially zero at the beginning of reform to 282 million in 2016, according to official statistics. Migrants represent more than half the urban labour force and account for a majority of the increase in the urban labour force since the beginning of economic reform. The combination of competition among cities and the migrant worker system was extraordinarily powerful. Shenzhen went from basically nothing to a city of 20 million people. The fact that the locations with the best investment climates could attract so many workers so quickly gave a strong boost to the overall growth rate of the economy. 
In trying to understand China's phenomenal growth record, a key reason has been this system in which local governments are given considerable autonomy, localities then compete intensely for investment and migrant workers and local officials are evaluated and promoted primarily on the basis of these economic results.

\section{Local innovation and scaling up}

The autonomy given to local governments also meant they could try out innovative approaches to providing public goods. Local governments everywhere face a host of challenges, from providing basic education to clean water and sanitation and protecting the natural environment. As the World Bank's country director based in Beijing from 2004 to 2009, I was fortunate to work with local governments all over China on their basic challenges in providing public goods. What struck me from that experience was that local governments often had clever innovations, and the ones that worked were quickly scaled up, either by other locales copying or by the success being codified in a national policy directive. I will illustrate this point with two examples in which the World Bank was involved. The point is not to exaggerate the role of the World Bank, which provided useful assistance in terms of introducing international experience. Rather, the point is to focus on the innovative role of local government. One example is from the urban arena and one from the rural.

The rural example involves the restoration of the Loess Plateau (World Bank 2007: 57). The plateau is an area of fine soil hundreds of kilometres west of Beijing covering parts of Shanxi, Shaanxi, Gansu, Ningxia and Inner Mongolia. By the 1980s, much of this area had been denuded through a combination of overexploitation by agriculture, grazing of sheep and goats and the removal of timber for use as fuel. It was this region that was the source of the sandstorms that plagued Beijing and other northern Chinese cities. Aside from the environmental problems, there were also tens of millions of people living in poverty because the lifestyle simply did not provide an adequate living.

During the period 1994-2005, two Loess Plateau watershed rehabilitation projects were carried out by local governments, with financial and technical support from the World Bank. The projects brought back the old idea of integrated rural development - something that has not worked well in most countries, often because local government does not have the capacity to implement a complex, cross-sectional project. The Loess Plateau projects were aimed at helping communities develop more sustainable lifestyles and offered a menu of options that could be tailored to suit by each community. A popular element was terracing of hilly terrain and planting of cash trees that do not require a lot of water. Some communities tried small-scale industrial activities, but these in general did not work well. Villages voted on what projects to implement and how to adjust in response to success or failure. 
One of the key activities previously in the Loess Plateau had been raising sheep and goats. Their unrestricted grazing was a key reason any green thing that started to appear would immediately be eaten. Experts recommended a ban on grazing for large parts of the plateau. This was too controversial to be adopted on a large scale, but a few communities that had invested in cash trees established grazing bans covering significant areas. What everyone learned from this experience was that mother nature, left to her own devices, could recover very quickly. Vast brown areas became vast green areas. When other communities saw the effect of the grazing ban, they quickly followed suit.

While the grazing ban was key to the environmental restoration of the plateau, it did leave a hole in the income of communities. Many communities had eked out a subsistence living by raising sheep and goats even though there was little grass for their foraging. With those activities stopped, some communities responded by shifting to raising pigs, which does not require grazing and can be done using animal feed. A successful component of the project promoted pig-raising as follows: one woman from the village was chosen as the pilot, given training and provided with an initial stock of piglets. She repaid the 'loan' by training other women in the village and providing them with piglets as her stock expanded. Visiting Loess Plateau villages in the mid-2000s, I was impressed that the women were using mobile phones to track pork prices in nearby cities. It also helped that there was a good expressway connecting once remote parts of the area to the cities. The mobile phones and the expressways are a reminder of how complicated development is: the various interventions that enabled the restoration of the natural environment in the Loess Plateau would have been useful in isolation, but were much more powerful as a package that included integration of the region with the national economy. Many elements of the project spread beyond the project area and became standard policies throughout the Loess Plateau.

The urban example of innovation and scaling up involves water supply and wastewater treatment (World Bank 2007: 37). At the beginning of its reform, China was underurbanised, with only 20 per cent of its population living in urban areas. One of the factors of economic dynamism noted above was the migration of hundreds of millions of people from the countryside to cities. The developing world is full of examples of cities that do not handle population growth well, unable to supply key urban services to the whole population. Even though China's urban population was small, only 50 per cent of it in 1990 was connected to the municipal water supply. More important, only 15 per cent had wastewater removal and treatment. Anyone who lived or travelled in China in the late 1980s or early 1990s will remember that rivers and lakes were fouled with untreated waste. This is a health hazard and an eyesore and nose-sore. The fact that the urban population roughly doubled between 1990 and 2005 greatly increased the scale of the challenge. 
It was noted in the previous section that China early on took a practical approach to economic infrastructure. But this definitely did not apply to water supply and sanitation, which were considered public goods provided largely free of charge by the city government. Prices for water were nominal and pricing for wastewater treatment nonexistent. The lack of prices meant that demand was surging uncontrollably, while resources did not exist to expand supply. The World Bank's work in this sector started with the four megacities of Beijing, Chongqing, Shanghai and Tianjin, and later spread to dozens of cities around the country. Shanghai pioneered the key reforms. It corporatised the department responsible for water and sanitation and set it on a self-sustaining financial course. It was given a mandate to operate along commercial lines and generate sufficient user revenue to cover operating costs and service debt. To this end, in 1989, Shanghai introduced the first sewerage tariff in the country. It was controversial, since people were used to getting this service for free, but it was necessary to expand the required wastewater treatment plants and associated sewer network. Shanghai's initial success in cleaning up its rivers prompted other cities to move in the same direction. By 1999, Shanghai's approach was adopted as national policy through a multi-ministerial notice. Despite the surging urban population nationwide, the wastewater treatment rate climbed only steadily, from 15 per cent in 1990 to 60 per cent in 2010 .

China's national policy goal is to move to full cost-recovery pricing, though it is not there yet. Still, the increased price of water has been significant and has had visible effects. Industrial use of water is down 30 per cent. And, despite rising per capita incomes, per capita water use in urban areas has been stable. The moves towards cost recovery have also made it possible to attract private investment into the sector, taking some of the fiscal burden off the state. There are now approximately 200 water or wastewater projects with private participation. Water and sanitation are a good example of national policy arising from local experimentation.

\section{Downsides of decentralisation and local autonomy}

While decentralisation and local autonomy have been very effective at generating investment and growth, the system does have some downsides and presents challenges for the future.

First, this model tends to put more value on growth than on other outcomes. The previous section highlighted some examples of how China is tackling various rural and urban environmental issues. Still, overall, China's development has taken a heavy toll on the environment. The country has many of the most air-polluted cities in the world and progress with cleaning up rivers and lakes has been greater in the south than in the north, where the water challenge is greater. If local officials 
are rewarded primarily for investment and growth during their typical five-year tenure in a position, they are not going to put sufficient weight on environmental considerations, especially ones whose main impact is long term. There has been much discussion within the party about broadening the criteria for evaluating local officials, but growth has remained the key evaluation criterion, along with political stability.

Second, the bukou system is a key factor behind the large rise in inequality that has occurred during China's reform. The average urban-rural income gap has risen above 3:1-one of the largest in the world. The hukou system puts labour at a disadvantage and locks the rural population out of better education and health services that are a foundation of human capital. There is ongoing discussion of reform of the hukou system, but local governments generally oppose this. Treating the vast migrant population as citizens would mean putting greater local fiscal resources into education, health, social security and housing.

Third, the negative effects of the hukou system are compounded by the extreme inequality in local government spending across Chinese jurisdictions. There is relatively little redistribution within China's fiscal system. This means that the more prosperous, faster-growing locales have large amounts of fiscal revenue, while poor, left-behind areas have few resources. From the point of view of growth, this is an efficient system in which the locales that can best use resources have the most resources; but the system is a problem from the point of view of equity. There are vast differences in the amounts spent on education and health in wealthy, coastal cities compared with the amounts spent in poor rural areas in the centre and west of the country. The children of migrants are literally 'left behind' in poor villages in which they receive poor-quality education. This is locking in inequality for the future. It will also eventually have a growth effect because these children will be the urban workforce of the future.

A fourth issue is that the current system skews incentives towards investment. China's overall investment rate has risen throughout the reform period and reached nearly 50 per cent of gross domestic product (GDP) in recent years. This raises questions about whether all this investment will in fact bear fruit in the future. For long-term growth, innovation and human capital accumulation are of central importance. But a local official trying to increase growth over a five-year period is not going to put much weight on those factors - they both take too long to pay off. The surest way to increase growth quickly would be new investment projects: constructing infrastructure and attracting factories to use it. Thus, the growth model does not put sufficient weight on human capital development and foundations of innovation such as intellectual property rights and a deep financial system. The old model worked exceptionally well as China grew from a low-income to a middleincome economy, but the next stage of development-from middle income to high income-relies less on factor accumulation and more on innovation. It is not clear 
whether China's mixed system of a large state sector and private initiative in some quarters will be able to generate sufficient innovation. The growth of total factor productivity in China's economy has slowed significantly in recent years, indicating that the investment-intensive model is running into diminishing returns, and that capital accumulation is not being replaced with innovation as a source of growth (Bai et al. 2016).

A final point is that the decentralised governance model in China favours results over rules. This approach creates a fertile environment for corruption. Corruption can deter investment and corrodes political order around a strong development objective. Certain types of corruption have flourished. All land in China is owned by the state. Farmers have use rights over agricultural land. But the government can take this land away with arbitrarily determined compensation. Many of the social and political disputes in China involve dispossessed farmers disgruntled at losing their land without compensation at full market value. Once local government has taken this land, it can auction it to developers and industrialists. If they pay the market price to use the land, this is a form of corruption that interferes little with the efficiency of investment, but rather is in the nature of a pure transfer from poor peasants to relatively well-off local officials. President Xi Jinping's anticorruption campaign has snared many 'tigers and flies' - that is, major and minor corrupt officials - but the only way to sustain reductions in corruption would involve institutional changes that provide more transparency and less discretion on the part of local officials.

In summary, local autonomy and the incentives to create good local investment climates and to innovate on public goods have all been important features of China's reform and its resulting success in achieving investment and growth. A lot of what has been successful in China's reform has bubbled up from below. At the same time, this system contributes to some of the key challenges that China now faces, including environmental degradation, rising inequality, overinvestment and government corruption.

\section{References}

Bai, C.-E., Hsieh, C.-T. and Song, Z. (2016), The long shadow of a fiscal expansion, Brookings Papers on Economic Activity, Washington, DC: Brookings Institution. doi.org/10.3386/w22801.

Dollar, D. (2008), Lessons from China for Africa, Policy Research Working Paper No. 4531, Washington, DC: The World Bank.

Eckaus, R. S. (1997), China, in P. Desai (ed.), Going Global: Transition from plan to market in the world economy, Cambridge, MA: MIT Press. 
Vogel, E. F. (2011), Deng Xiaoping and the Transformation of China, Cambridge, MA: Harvard University Press. doi.org/10.4159/harvard.9780674062832.

World Bank (2004), World Development Report: A better investment climate for everyone, Washington, DC: The World Bank.

World Bank (2007), China and the World Bank: A partnership for innovation, Washington, DC: The World Bank. Available from: documents.worldbank.org/ curated/en/339171468025448074/China-and-the-World-Bank-a-partnershipfor-innovation. 
This text is taken from China's 40 Years of Reform and Development: 1978-2018, edited by Ross Garnaut, Ligang Song and Cai Fang, published 2018 by ANU Press, The Australian National University, Canberra, Australia.

doi.org/10.22459/CYRD.07.2018.09 